\title{
In Vitro Lymphocyte Functions in Undernourished Children With Sickle Cell Anemia
}

\author{
Solo R. Kuvibidila, PhD, ${ }^{1}$ Renée Gardner, MD, ${ }^{1}$ Maria C. Velez, MD, ${ }^{1}$ Lolie Yu, MD, ${ }^{1}$ Rajasekharan P. Warrier, MD ${ }^{1,2,3}$ \\ ${ }^{1}$ Department of Pediatrics, Division of Hematology/Oncology, Louisiana State University Health Sciences Center, New Orleans, LA \\ ${ }^{2}$ Department of Pediatrics, Division of Hematology/Oncology, Ochsner Children's Hospital, New Orleans, LA ${ }^{3}$ The University of Queensland \\ Faculty of Medicine, Ochsner Clinical School, New Orleans, LA
}

Background: Children with sickle cell disease (SCD) often suffer from growth deficits and impaired immunity. However, the association between mild to moderate malnutrition and in vitro lymphocyte function has not been well studied. The goal of this study was to investigate the effects of undernutrition on lymphocyte functions in children with SCD.

Methods: Weight; height; plasma concentrations of albumin (Alb), prealbumin (PA), transferrin (Tf), retinol-binding protein (RBP), $\alpha_{1}$-acid glycoprotein (AGP), C-reactive protein (CRP), and ceruloplasmin (Cp); and lymphocyte proliferation and interleukin (IL)-2 in phytohemagglutinin-treated blood lymphocytes were measured in 90 children with SCD (59 SS, 4 S $\beta^{\circ}, 27 \mathrm{SC}$ hemoglobin genotypes).

Results: The mean age of the children included in the analysis was 7.65 years. Four of the 90 children had weight and height below the fifth percentile. A higher percentage of children with $\mathrm{HbSS} / \mathrm{HbS} \beta^{\circ}(61.4 \%)$ than of those with $\mathrm{HbSC}(44 \%)$ had $\geq 2$ plasma protein concentrations below normal (Alb $<35 \mathrm{~g} / \mathrm{L}, \mathrm{PA}<160 \mathrm{mg} / \mathrm{L}, \mathrm{Tf}<2.0 \mathrm{~g} / \mathrm{L}$, and RBP $\leq 20 \mathrm{mg} / \mathrm{L}$ ). Mean anthropometric measurements, hemoglobin, and hematocrit were lower in children with $\mathrm{HbSS} / \mathrm{HbS}^{\circ}$ than in those with HbSC $(P<0.05)$. Lymphocyte proliferation was reduced by $20 \%$ to $27 \%$ in children with $\mathrm{HbSS} / \mathrm{HbS} \beta^{\circ}$ with undernutrition plus inflammation (AGP $>1 \mathrm{~g} / \mathrm{L}, \mathrm{CRP}>5 \mathrm{mg} / \mathrm{L}, \mathrm{Cp}>600 \mathrm{mg} / \mathrm{L}$ ) compared to children with neither. Regardless of inflammatory status, lymphocyte proliferation was reduced by $29 \%$ to $49 \%$ in children with $\mathrm{HbSS} / \mathrm{HbS}^{\circ}$ and undernutrition defined by PA or Alb plus RBP $(P<0.05)$ compared to those with RBP within normal range. Neither undernutrition nor inflammation reduced lymphocyte proliferation in children with HbSC. Mean IL-2 activity was reduced by undernutrition, defined as PA $<160 \mathrm{mg} / \mathrm{L}$, in both groups. PA, RBP, and hemoglobin concentrations positively correlated with in vitro lymphocyte functions $(P<0.05)$.

Conclusion: Undernutrition altered in vitro lymphocyte function in children with the $\mathrm{HbSS} / \mathrm{HbS} \beta^{\circ}$ genotypes. Dietary supplements may improve the altered functions in these children.

Keywords: Albumin, anemia-sickle cell, anthropometry, ceruloplasmin, C-reactive protein, interleukin-2, lymphocyte proliferation, prealbumin, retinol-binding protein, undernutrition

Address correspondence to Solo R. Kuvibidila, PhD, clo Renée Gardner, MD, Department of Pediatrics, Division of Hematology/Oncology, Louisiana State University Health Sciences Center, 200 Henry Clay Ave., New Orleans, LA 70118. Tel: (504) 896-9740. Email: solokuv@msn.com

\section{INTRODUCTION}

Severe protein-energy malnutrition (PEM) and/or micronutrient deficiencies in humans and laboratory animals impair innate and adaptive immunity. ${ }^{1-3}$ However, the effects of mild to moderate PEM on immune function is less clear. We do know that mild to moderate PEM in humans impairs some (eg, delayed type hypersensitivity) but not other (eg, antibody responses to vaccination) immune functions. ${ }^{4}$ Lymphocyte proliferation, one of the tests used to assess in vitro lymphocyte function, is usually reduced by severe PEM. ${ }^{1,3}$ The mechanisms involved may include changes in lymphocyte subsets and reduced secretion or gene expression of cytokines and various molecules (eg, interleukin [IL]-2, IL-4, IL-17, cyclins) that regulate cell proliferation. ${ }^{1}$

Young children with sickle cell disease (SCD), especially those with the hemoglobin ( $\mathrm{Hb})$-SS genotype, often have growth deficits and impaired immunity. ${ }^{4-8}$ The mechanisms of growth deficits are multifactorial and involve inadequate food intake (eg, during episodes of pain crisis and/or infection), increased resting energy expenditure because of increased red blood cell production, and increased nutrient loss resulting from red blood cell destruction. ${ }^{9-10}$ Reduced nutrient absorption-specifically vitamins and minerals-during infection or because of chronic inflammation is another mechanism that may lead to nutrient 
insufficiency. ${ }^{10-13}$ Providing dietary supplementation with zinc and/or other nutrients to children with growth deficits has resulted in improved growth measurements in studies with small cohorts. ${ }^{14-17}$

Possible mechanisms of impaired immunity include nutrient deficiencies, iron overload because of blood transfusion, alloimmunization, and splenic dysfunction. ${ }^{14}$ Specific changes in adaptive and innate immunity include the reduced proportion of circulating CD4+ and CD8+ T cells and a shift from TH1 (interferon gamma and IL-2) to TH2 (IL-6 and IL-4) cytokine response. ${ }^{10}$ Elevated numbers of nonfunctional neutrophils, defective macrophages, natural killer cells, and T regulatory cells have also been observed. ${ }^{11}$ Increased blood levels of proinflammatory cytokines, including tumor necrosis factor alpha (TNF- $\alpha$ ) and acute phase proteins (eg, C-reactive protein [CRP]), have been reported as well. ${ }^{12-18} \mathrm{~A}$ few studies, although conducted on a limited number of children, have shown that dietary supplements (eg, zinc) improved in vitro immune function and reduced infection rates. ${ }^{14,16,17}$

We have observed that lymphocyte proliferation and IL-2 secretion tend to be lower in children with SCD who have suboptimal vitamin A status vs those with adequate plasma retinol levels. ${ }^{19}$ In a previous small study, we reported that nearly $53 \%$ of the children with SCD had plasma levels of retinol-binding protein (RBP) $<30 \mathrm{mg} / \mathrm{L}$, but no child had albumin (Alb) levels $<35 \mathrm{~g} / \mathrm{L} .{ }^{20}$ The study suggested the presence of mild to moderate PEM in our SCD patient population. The effects of mild to moderate PEM on in vitro lymphocyte function in patients with SCD have not been well studied.

We designed this study to investigate (1) the effect of mild to moderate PEM on in vitro immune responses of peripheral blood mononuclear cells in children with SCD and (2) whether $\mathrm{Hb}$ genotype and inflammation are confounding factors in impaired lymphocyte function.

\section{METHODS}

\section{Study Population and Design}

The study was approved by the institutional review boards of Louisiana State University Health Sciences Center and the Children's Hospital of New Orleans. Patients included in the analysis presented in this paper were enrolled in a prospective study in which we sought to investigate the associations among nutritional status, in vitro immune functions, inflammatory cytokines, and certain complications (including pain crisis episodes, infection, blood transfusion requirements, and hospitalizations) often observed in children with SCD. Our data on inflammatory cytokines (TNF- $\alpha$ ), the association between vascular cell adhesion molecule1 and zinc levels, lymphocyte proliferation as a function of plasma retinol concentration, and clinical status have been previously published. ${ }^{18,19,21}$

Inclusion criteria were boys and girls with $\mathrm{HbSS}$, HbSC, and/or $\mathrm{HbS} \beta^{\text {thalassemia }}\left(\mathrm{HbS} \beta^{\text {thal-0 }}\right)$ genotypes who were 0.5 to 18 years old. Exclusion criteria were children who (1) were on hydroxyurea at the time of recruitment, (2) had received a bone marrow transplant, (3) had had a splenectomy, and (4) were hospitalized at the time of blood drawing. Ninety children met the inclusion criteria.

Because only 4 children had the $\mathrm{HbS}^{\circ}$ genotype and because the disease in children with this genotype is usu- ally as severe as that observed in children with HbSS, we combined the 2 subgroups for analysis. ${ }^{22}$

\section{Measurement of Indicators of Nutritional Status and Inflammation}

Blood samples were collected in heparinized vacutainers in children under stable conditions. After removing $200 \mu \mathrm{L}$ of blood for the measurement of $\mathrm{Hb}$, hematocrit, and white blood cell count by standard techniques, the remaining blood samples were centrifuged at $400 \times \mathrm{g}$ for 10 minutes. Plasma was aspirated and immediately frozen at $-70^{\circ} \mathrm{C}$ until used for various measurements.

Biochemical indicators of nutritional status-Alb, prealbumin (PA), transferrin (Tf), and RBP-were measured in plasma by radial immunodiffusion. The cutoff points to define undernutrition were Alb $<35 \mathrm{~g} / \mathrm{L}, \mathrm{PA}<160 \mathrm{mg} / \mathrm{L}$, Tf $<2.0 \mathrm{~g} / \mathrm{L}$, and RBP $\leq 20 \mathrm{mg} / \mathrm{L} .{ }^{23,24}$ Growth deficits were present when either weight or height was below the fifth percentile. Regardless of the weight and height percentile, children with at least 2 plasma proteins below the proposed cutoff points were considered to have mild to moderate PEM.

Inflammation was assessed through the measurement of CRP, $\alpha_{1}$-acid glycoprotein (AGP), and ceruloplasmin (Cp) in plasma by radial immunodiffusion. Inflammation was defined based on the most recent cutoff points proposed by the World Health Organization: AGP $>1 \mathrm{~g} / \mathrm{L}, \mathrm{CRP}>5 \mathrm{mg} / \mathrm{L}$, and $\mathrm{Cp}>600 \mathrm{mg} / \mathrm{L} .{ }^{25,26}$

\section{Lymphocyte Proliferation}

Details for the isolation of mononuclear cells and culture conditions for lymphocyte proliferation have been previously described. ${ }^{19,27}$ The culture medium contained RPMI-1640, $10 \%$ heat-inactivated human $A B$ serum, $5 \times 10^{4}$ units penicillin, $50 \mathrm{mg}$ streptomycin, $1 \mathrm{mmol}$ sodium pyruvate, $0.1 \mathrm{mmol}$ nonessential amino acids, $2 \mathrm{mmol}$ L-glutamine, and $50 \mu \mathrm{mol} \beta$-mercaptoethanol (per 1,000 mL). Lymphocyte proliferation (of triplicate cultures containing $2 \times 10^{5}$ viable cells $/ 200 \mu \mathrm{L}$ medium) was assessed by the rate of ${ }^{3} \mathrm{H}$-thymidine incorporated into DNA. ${ }^{18}$ Results are expressed as stimulation indexes that are the ratios of counts per minute (CPM) in the presence of 2.5 to $20 \mu \mathrm{g} / \mathrm{mL}$ phytohemagglutinin (PHA) over baseline CPM (obtained in cells incubated without PHA).

\section{Interleukin-2 Study}

Macrocultures $\left(2 \times 10^{6}\right.$ viable cells $\left./ \mathrm{mL}\right)$ containing 0 to $20 \mu \mathrm{g} \mathrm{PHA}$ were incubated at $37^{\circ} \mathrm{C}$ and $5 \% \mathrm{CO}_{2}$ in a humidified atmosphere. ${ }^{19,28}$ After 48 hours, cultures were centrifuged, and the supernatant was collected and immediately frozen at $-70^{\circ} \mathrm{C}$. The IL-2 activity in the supernatant was estimated by the growth rate of IL-2-dependent CTLL-2 cells assessed by ${ }^{3} \mathrm{H}$-thymidine uptake. ${ }^{27}$ In the absence of IL2, CTLL-2 cells (which are derived from murine cytotoxic $T$ cells) do not undergo cell multiplication. ${ }^{28}$

\section{Statistical Analysis}

Means \pm standard error of the mean (SEM), analysis of variance, Pearson correlation coefficients, and chi-square test were performed by Microstat Program (Microsoft Inc.). ${ }^{29}$

Lymphocyte proliferative responses to PHA and IL-2 concentrations were analyzed as a function of $\mathrm{Hb}$ genotypes, undernutrition, and inflammation. Multiple regression 
Table 1. Demographic Variables and Mean Indicators of Nutritional Status, Hematologic Measurements, and Acute Phase Proteins as a Function of Hemoglobin Genotype

\begin{tabular}{|c|c|c|}
\hline Variable/Indicator & $\begin{array}{c}\mathrm{HbSS} / \mathrm{HbS} \beta^{\circ} \text { Genotypes } \\
\text { Subgroup } \\
n=63\end{array}$ & $\begin{array}{c}\text { HbSC Genotype } \\
\text { Subgroup } \\
n=27\end{array}$ \\
\hline Boys: Girls & $34: 29$ & $16: 11$ \\
\hline Age, years & $8.28 \pm 0.53^{a}$ & $6.46 \pm 0.86^{b}$ \\
\hline Weight percentile & $33.75 \pm 3.70^{b}$ & $63.41 \pm 6.87^{\mathrm{a}}$ \\
\hline Weight Z-score & $-0.52 \pm 0.14^{b}$ & $0.45 \pm 0.10^{\mathrm{a}}$ \\
\hline Height percentile & $38.05 \pm 4.17^{b}$ & $68.73 \pm 6.75^{\mathrm{a}}$ \\
\hline Height Z-score & $-0.37 \pm 0.15^{b}$ & $0.92 \pm 0.24^{\mathrm{a}}$ \\
\hline White blood cells $\times 10^{6} / \mathrm{mL}$ & $12.38 \pm 0.68^{\mathrm{a}}$ & $9.49 \pm 0.78^{b}$ \\
\hline Hemoglobin, g/dL & $8.27 \pm 0.18^{b}$ & $11.11 \pm 0.26^{\mathrm{a}}$ \\
\hline Hematocrit, $\%$ & $26.22 \pm 0.60^{b}$ & $32.39 \pm 0.49^{a}$ \\
\hline Albumin, $g / L$ & $41.54 \pm 0.98$ & $38.99 \pm 1.45$ \\
\hline Prealbumin, mg/L & $133.73 \pm 7.16^{b}$ & $160.72 \pm 12.65^{a}$ \\
\hline Transferrin, g/L & $2.36 \pm 0.07$ & $2.52 \pm 0.13$ \\
\hline Retinol binding protein, $\mathrm{mg} / \mathrm{L}$ & $18.70 \pm 0.95^{b}$ & $25.82 \pm 1.93^{\mathrm{a}}$ \\
\hline$\alpha_{1}$ acid-glycoprotein, $\mathrm{g} / \mathrm{L}$ & $0.66 \pm 0.03$ & $0.73 \pm 0.04$ \\
\hline C-reactive protein, $\mathrm{mg} / \mathrm{L}$ & $5.87 \pm 1.52$ & $2.35 \pm 1.01$ \\
\hline Ceruloplasmin, mg/L & $495.50 \pm 18.35$ & $478.00 \pm 29.00$ \\
\hline
\end{tabular}

Notes: Data are presented as means \pm standard error of the mean. For each measurement, means of both groups with different superscript letters are statistically different: $\mathrm{a}>\mathrm{b} ; P<0.05$.

analysis was computed with IL-2 and/or lymphocyte proliferation as dependent variables and health status (weight, height, acute phase proteins, transport proteins, and hematologic measurements) as independent variables. The level of significance was set at $P<0.05$. $P$ values between 0.05 and 0.07 were considered to indicate a trend of difference.

\section{RESULTS}

\section{Assessment of Nutritional Status}

Demographic data of the patients are summarized in Table 1. The mean \pm SEM age of the 90 patients (50 boys and 40 girls) was $7.65 \pm 0.45$ years. The percent of children by $\mathrm{Hb}$ genotype was $65.6 \% \mathrm{HbSS}, 30 \% \mathrm{HbSC}$, and $4.4 \%$ $\mathrm{HbS} \beta^{\circ}$. Children with the HbSC genotype were younger than those with the $\mathrm{HbSS} / \mathrm{HbS} \beta^{\circ}$ genotypes $(P<0.05)$.

Children in the $\mathrm{HbSS} / \mathrm{HbS} \beta^{\circ}$ subgroup had significantly lower means for weight and height percentiles and for weight and height Z-scores than those in the HbSC subgroup $(P<0.05)$. At the time of blood drawing, 4 children (3 with $\mathrm{HbSS}$ and 1 with $\mathrm{HbS} \beta^{\circ}$ ) had weight and height less than the fifth percentile.

The white blood cell count mean was higher, and the means of $\mathrm{Hb}$ and hematocrit were lower in the subgroup of children with $\mathrm{HbSS} / \mathrm{HbS}^{\circ}$ vs the subgroup of children with HbSC $(P<0.05)$.

The mean concentrations of Alb were within the normal range for both subgroups of children (Table 1). While the mean concentration of PA was within the normal range in children with the HbSC genotype, the PA mean was below normal in the children with the $\mathrm{HbSS} / \mathrm{HbS} \beta^{\circ}$ genotypes. The mean concentration of RBP was also below normal in children with the $\mathrm{HbSS} / \mathrm{HbS} \beta^{\circ}$ genotypes. Children with the $\mathrm{HbSS} / \mathrm{HbS}^{\circ}$ genotypes had lower mean concentrations of $\mathrm{PA}, \mathrm{Tf}$, and RBP than the children with the HbSC genotype $(P<0.05)$. A slightly and nonsignificantly higher percentage of children with the $\mathrm{HbSS} / \mathrm{HbS} \beta^{\circ}$ genotypes $(61.4 \%)$ vs children with the HbSC genotype (44\%) had 2 to 4 plasma proteins in the range suggestive of undernutrition $\left(\chi^{2}=1.5\right.$, $P=0.22)$.

We observed no significant difference in the mean concentrations of AGP and Cp among both subgroups of children (Table 1). Although the mean CRP concentration in children with $\mathrm{HbSS} / \mathrm{HbS} \beta^{\circ}$ genotypes was approximately 2.5 times higher than that for children with the HbSC genotype, the difference was not significant.

The percentages of children with inflammation, defined by any of the 3 acute phase proteins, were approximately $44 \%$ and $45 \%$ for children with the $\mathrm{HbSS} / \mathrm{HbS} \beta^{\circ}$ and $\mathrm{HbSC}$ genotypes, respectively.

\section{Lymphocyte Proliferation as a Function of Hemoglobin Genotype and Biochemical Indicators of Nutritional Status}

In the subgroup of children with the $\mathrm{HbSS} / \mathrm{HbS} \beta^{\circ}$ genotypes, mild to moderate PEM was associated with a nonsignificant decrease $(9.6 \%$ to $29 \%$, mean $15 \%)$ in mean lymphocyte proliferative responses to PHA concentrations (Figure 1A). In children with the HbSC genotype, the opposite was observed: mild to moderate PEM was associated with a $22 \%$ to $88 \%$ increase in mean stimulation indexes compared 


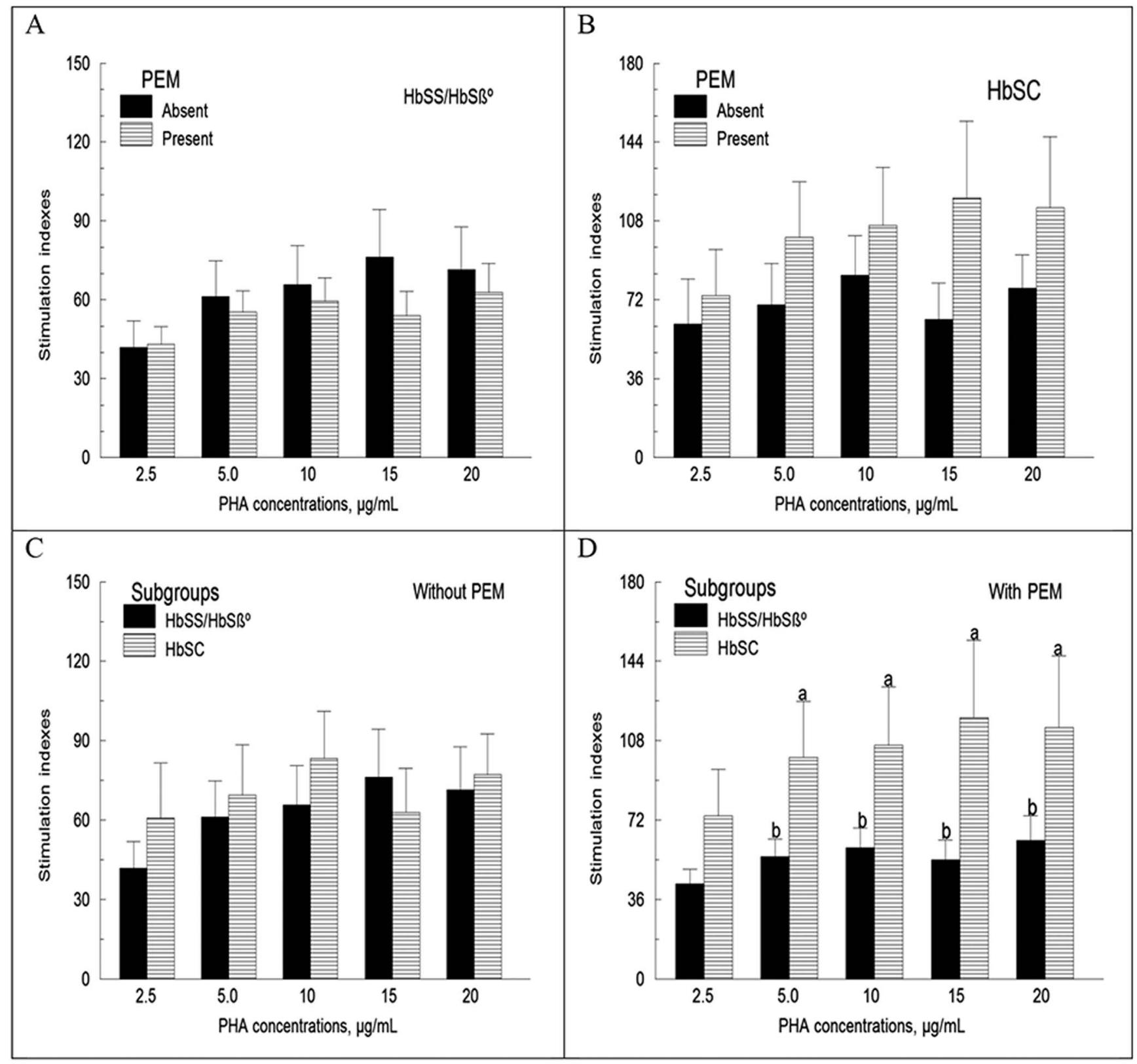

Figure 1. Lymphocyte proliferation as a function of mild to moderate protein-energy malnutrition (PEM) and hemoglobin (Hb) genotype expressed as stimulation indexes. Mononuclear cells were incubated with and without phytohemagglutinin (PHA) for $\mathbf{4 8}$ hours before being pulsed with ${ }^{3} \mathrm{H}$-thymidine for $\mathbf{2 4}$ hours. Results are expressed as stimulation indexes or the ratio of the amount of radioactivity incorporated into DNA by cells incubated with PHA over baseline. Sample sizes for PEM absent vs PEM present are as follows: $\mathrm{HbSS} / \mathrm{HbS} \beta^{\circ}, 21$ vs 34 and $\mathrm{HbSC}, 12$ vs 15 . Values are means \pm standard error of the mean. In Figure 1D, the means of patients in the HbSC subgroup are higher than those of patients in the $\mathrm{HbSS} / \mathrm{HbS} \beta^{\circ}$ subgroup $(\mathrm{a}>\mathrm{b}$; $P<0.05)$.

to those without PEM (Figure 1B). In children without PEM, we found no significant difference in mean lymphocyte proliferative responses to $\mathrm{PHA}$ concentrations between the $\mathrm{Hb}$ genotype subgroups (Figure 1C). In children with PEM, lymphocyte proliferation was lower in the subgroup of children with the $\mathrm{HbSS} / \mathrm{HbS} \beta^{\circ}$ genotypes vs those with the $\mathrm{HbSC}$ genotype $(P<0.05)$ (Figure 1D).

We also compared mean stimulation indexes among children with the $\mathrm{HbSS} / \mathrm{HbS}^{\circ}$ genotypes as a function of RBP combined with either PA, Alb, or Tf. Four subgroups were defined: (1) normal range concentrations of RBP and the other protein, (2) normal RBP and low concentration of the other protein, (3) below normal RBP and normal concentration of the other protein, and (4) below normal concentrations of RBP and the other protein.

Regardless of the PA and Alb concentrations (normal or below normal range), mean lymphocyte proliferative responses of cells obtained from children with the 
$\mathrm{HbSS} / \mathrm{HbS} \beta^{\circ}$ genotypes and RBP below normal (subgroups 3 and 4) tended to be lower than those of children with RBP within the normal range (subgroups 1 and 2) (Figures $2 A$ and 2B). Mean lymphocyte proliferation also tended to be lower in children with the $\mathrm{HbSS} / \mathrm{HbS}^{\circ}$ genotypes, RBP below normal, and Tf within or below normal range (subgroups 3 and 4) vs with those with normal RBP concentrations and Tf below normal range (subgroup 2) (Figure 2C). Differences were statistically significant $(P<0.05)$ among the 4 subgroups for some but not all PHA concentrations (Figure 2).

We did not analyze data as a function of RBP in combination with the other 3 transport proteins for children with the $\mathrm{HbSC}$ genotype because too few children met the criteria for the 4 subgroups defined above.

\section{Lymphocyte Proliferation as a Function of Inflammation}

Inflammation did not significantly alter lymphocyte proliferation in children with the $\mathrm{HbSS} / \mathrm{HbS} \beta^{\circ}$ genotypes (Figure 3A). However, inflammation had the opposite effect in the subgroup of children with the HbSC genotype (Figure 3B). In children without inflammation, lymphocyte proliferation was not different among the children with different $\mathrm{Hb}$ genotypes (Figure $3 \mathrm{C}$ ), but in children with inflammation, lymphocyte proliferative responses to PHA concentrations were lower in children with the $\mathrm{HbSS} / \mathrm{HbS} \beta^{\circ}$ genotype vs those with the HbSC genotype $(P<0.05)$ (Figure 3D).

We also analyzed lymphocyte proliferation in children with the $\mathrm{HbSS} / \mathrm{HbS}^{\circ}$ genotypes as a function of both undernutrition and inflammation. Four subgroups were defined: (1) without undernutrition or inflammation, (2) without undernutrition but with inflammation, (3) with undernutrition but without inflammation, and (4) with both undernutrition and inflammation. Although the differences did not reach statistical significance, the mean stimulation indexes of cells treated with PHA concentrations between 5 and $20 \mu \mathrm{g} / \mathrm{mL}$ from children with both undernutrition and inflammation were $20 \%$ to $27 \%$ lower than those of children without either problem (Figure 4).

We did not analyze lymphocyte proliferation as a function of undernutrition and inflammation for children with the HbSC genotype because too few children met the criteria for the 4 subgroups defined above.

\section{Interleukin-2 Concentration as a Function of Undernutrition and Inflammation}

In the subgroup of children with the $\mathrm{HbSS} / \mathrm{HbS} \beta^{\circ}$ genotypes, undernutrition did not significantly affect mean IL-2 activity (Table 2). However, in the same children, undernutrition reduced the medians of IL-2 activity in 2 of the 4 cultures by $25.9 \%$ to $44.4 \%$. Although the changes did not reach statistical significance, undernutrition slightly reduced the means and medians of IL-2 activity in 3 of the 4 cultures from children with the HbSC genotype.

We also analyzed IL-2 data as a function of individual plasma proteins. For children in both $\mathrm{Hb}$ genotype subgroups and for each PHA concentration tested, the mean IL-2 activity of children with $P A$ in the normal range $(\geq 160$ $\mathrm{mg} / \mathrm{L})$ was higher than that for children with $\mathrm{PA}<160 \mathrm{mg} / \mathrm{L}$ (Figure 5). This difference attained significance $(P<0.05)$ only in the $\mathrm{HbSS} / \mathrm{Hb} \beta^{\circ}$ genotype subgroup. The analysis of other

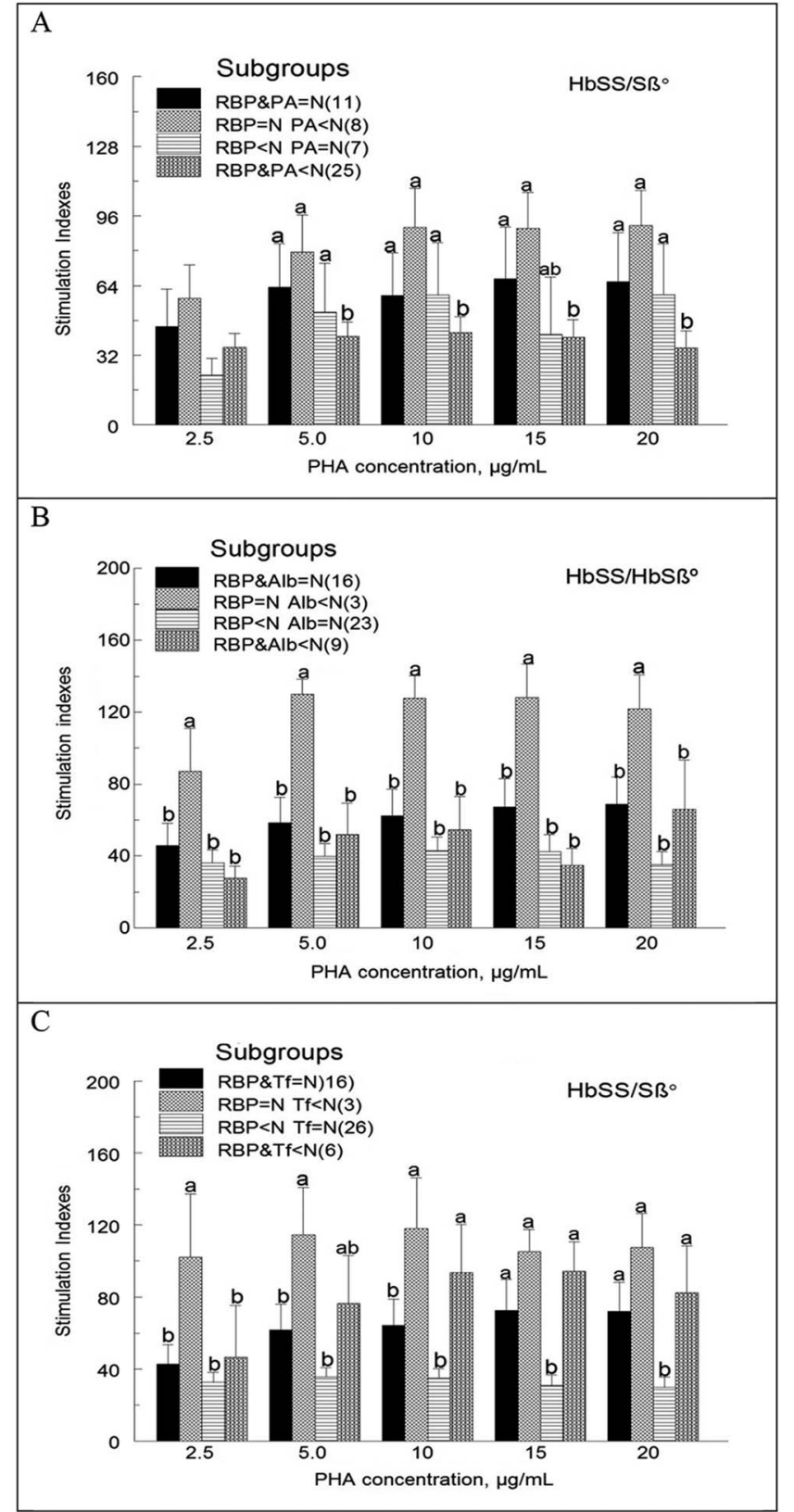

Figure 2. The effects of retinol binding protein (RBP) in combination with other transport proteins on lymphocyte proliferation in the subgroup of children with the $\mathrm{HbSS}$ or $\mathrm{HbS} \beta^{\circ}$ genotype. Mononuclear cells were incubated with and without phytohemagglutinin (PHA) before being pulsed with ${ }^{3} \mathrm{H}-$ thymidine as explained in the legend for Figure 1. The 4 subgroups in view A are as follows: normal RBP and prealbumin (PA); normal RBP, below normal PA; below normal RBP, normal PA; below normal RBP and PA. In views $B$ and $C$, PA is replaced by albumin (Alb) and transferrin (Tf), respectively. For each subgroup, numbers in parentheses are the sample sizes. Values are means \pm standard error of the mean. For each PHA concentration, mean stimulation indexes (depicted as bars) among the 4 subgroups denoted with the letter $a$ are higher than those denoted with the letter $b(a>b$; $P<0.05)$. 


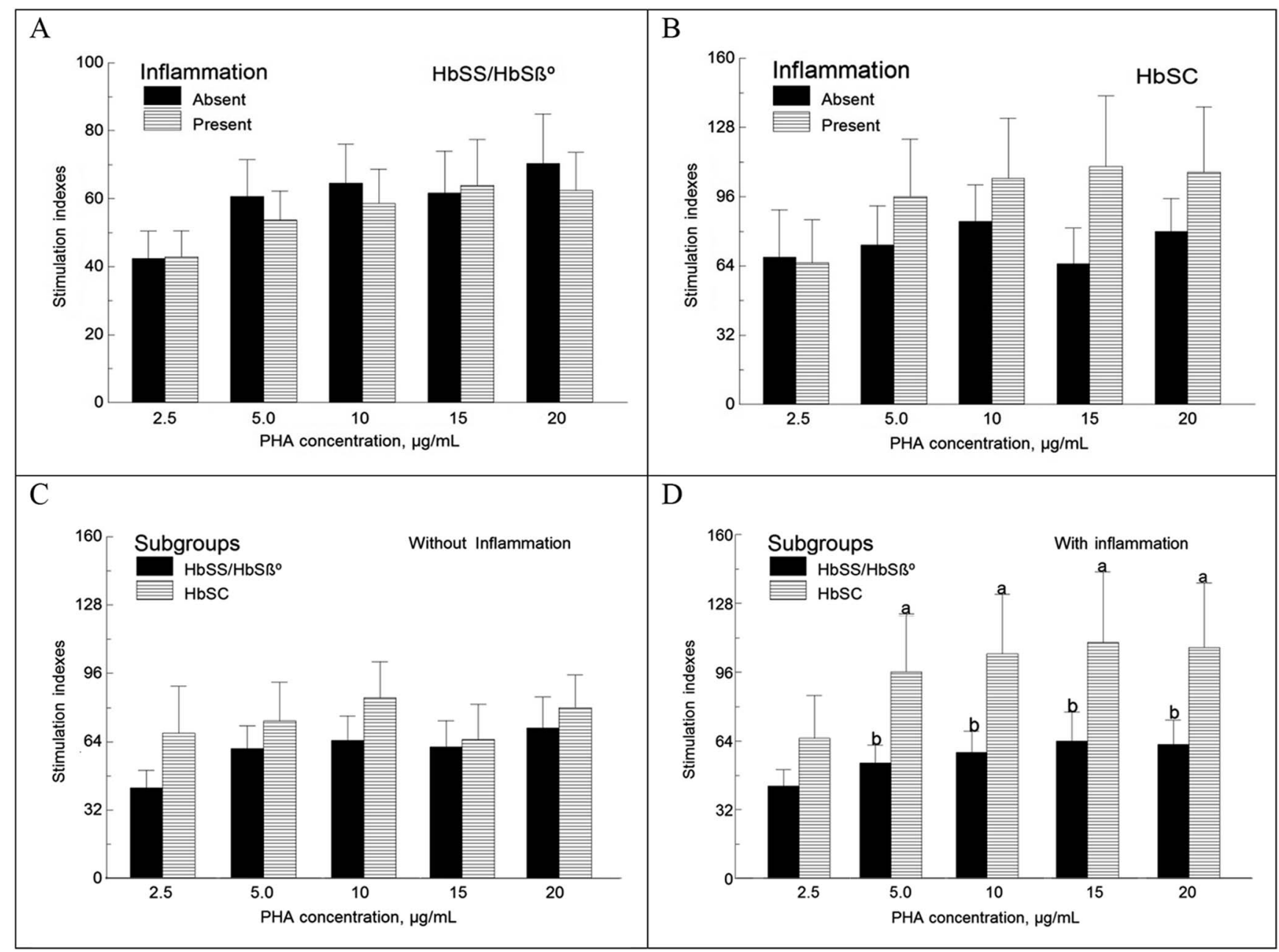

Figure 3. Effect of inflammation on lymphocyte proliferation in children with the HbSS/HbS $\beta^{\circ}$ genotypes and those with the HbSC genotype. Mononuclear cells were incubated with and without phytohemagglutinin (PHA) for 48 hours before being pulsed with ${ }^{3} \mathrm{H}$-thymidine for $\mathbf{2 4}$ hours. Results are expressed as stimulation indexes or the ratio of the amount of radioactivity incorporated into DNA by cells incubated with PHA over baseline. In views A and B, sample sizes are 31 vs 24 and 13 vs 8 for the $\mathrm{HbSS} / \mathrm{HbS} \beta^{\circ}$ and $\mathrm{HbSC}$ subgroups, respectively. Values are means \pm standard error of the mean. In the presence of inflammation, the mean stimulation indexes of children with the $\mathrm{HbSC}$ genotype were higher than those of children with the $\mathrm{HbSS} / \mathrm{HbS} \beta^{\circ}$ genotypes $(\mathrm{a}>\mathrm{b} ; \mathrm{P}<0.05)$.

transport proteins (alone or in combination with RBP) did not show such a clear trend (data not shown).

Inflammation did not significantly alter IL-2 activity in cells prepared from children in either of the genotype subgroups (Table 3). Regardless of inflammation status, for each PHA concentration tested, the means for IL-2 activity were not significantly different between the children with the $\mathrm{HbSS} / \mathrm{Hb} \beta^{\circ}$ genotypes and those with the HbSC genotype.

\section{Correlation Coefficients and Multiple Regression Analysis}

We observed positive and significant correlations between lymphocyte proliferative responses to PHA concentrations and both RBP and $\mathrm{Hb}(P<0.05)$ but not for the other indicators of nutritional status (Table 4$)$. While IL-2 activity positively correlated with $\mathrm{PA}(P<0.05)$ and weight percentiles $(P>0.05)$, it negatively correlated with white blood cell counts
$(P<0.05)$ and also negatively correlated with Alb $(P<0.05)$. IL-2 did not correlate with other indicators of nutritional status or $\mathrm{Hb}$. However, as one would expect, IL-2 negatively correlated with white blood cell counts (PHA 5 and PHA 10; $P<0.05)$. Acute phase proteins did not significantly correlate with either lymphocyte proliferative responses to PHA or IL-2 activity (data not shown). Multiple regression analysis did not show any significant association between lymphocyte proliferative responses and/or IL-2 with any one specific indicator of nutritional status (data not shown).

\section{DISCUSSION}

The limited available data for patients with SCD suggest that lymphocyte proliferation can be reduced, normal, or occasionally increased compared to subjects without SCD. ${ }^{30-32}$ Differences in lymphocyte proliferation between patients with SCD and subjects without SCD may be related to disease severity (concentrations of sickle [S] and fetal 


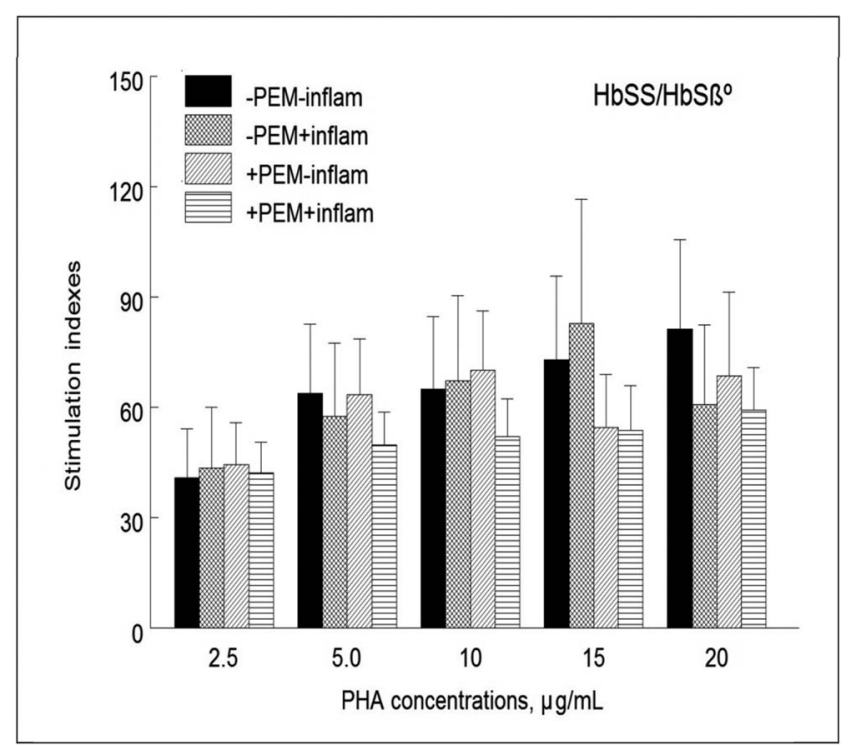

Figure 4. Lymphocyte proliferation in the subgroup of children with the $\mathrm{HbSS} / \mathrm{HbS} \beta^{\circ}$ genotypes as a function of undernutrition (protein-energy malnutrition [PEM]) without and with inflammation (inflam). Mononuclear cells were incubated with and without phytohemagglutinin (PHA) before being pulsed with ${ }^{3} \mathrm{H}$-thymidine for 24 hours as explained in the legend for Figure 1. Results are expressed as stimulation indexes. The 4 subgroups are as follows: no PEM or inflammation ( $n=13)$; no PEM, inflammation $(n=8)$; PEM, no inflammation $(n=14)$; PEM and inflammation $(n=20)$. Values are means \pm standard error of the mean. For each PHA concentration, analysis of variance did not detect significant differences among the 4 subgroups of children.
[F] Hb), spleen dysfunction, undernutrition, frequent pain crisis episodes, or infection. ${ }^{32}$

The following are the most important observations from our study.

1. Our results are in accordance with those of Martyres et al who reported that severe growth deficits were uncommon in a study of Canadian children with sickle cell anemia, very likely because of excellent healthcare and disease management. ${ }^{13}$ The low prevalence of severe growth deficits may also suggest that macronutrient intake and utilization were adequate.

2. At the time of recruitment, the prevalence of mild to moderate PEM diagnosed by at least 2 plasma proteins was higher in the subgroup of children with $\mathrm{HbSS} / \mathrm{HbS} \beta^{\circ}$ disease vs those with the HbSC genotype. The higher prevalence of PEM in the subgroup of children with $\mathrm{HbSS} / \mathrm{HbS} \beta^{\circ}$ genotypes is in agreement with disease severity as previously reported. ${ }^{22}$

3. Contrary to what we expected, mild to moderate PEM assessed by transport proteins only slightly decreased lymphocyte proliferation in children with the $\mathrm{HbSS} / \mathrm{HbS} \beta^{\circ}$ genotypes and had no negative effect in those with the $\mathrm{HbSC}$ genotype. We speculate that the lack of significant negative effect of PEM on lymphocyte proliferation in these patients is very likely because of the mild form of malnutrition. This speculation is supported by the low number of children who had growth deficits. We must add that lymphocyte proliferative responses to PHA concentrations tended to be reduced in children with the $\mathrm{HbSS} / \mathrm{HbS}^{\circ}$ genotypes with both PEM and inflammation vs those without PEM \pm inflammation. This observation suggests that the health status of children with both

Table 2. Effect of Mild to Moderate Protein-Energy Malnutrition (PEM) on Interleukin-2 Activity in Phytohemagglutinin (PHA)Treated Peripheral Blood Mononuclear Cells as a Function of Hemoglobin Genotype

Interleukin-2 Activity, IU/mL

Group

\begin{tabular}{cc}
\hline Genotype & PHA, $\mu \mathrm{g} / \mathrm{mL}$ \\
\hline
\end{tabular}

$\mathrm{HbSS} / \mathrm{HbS} \beta^{\circ}$ subgroup

$\begin{array}{cll}0 & 1.11 \pm 0.34 & 0.96 \\ 5 & 5.34 \pm 1.09 & 5.33 \\ 10 & 4.32 \pm 1.07 & 2.77 \\ 20 & 7.92 \pm 5.49 & 2.66\end{array}$

Without PEM

$\overline{\text { Mean } \pm \text { SEM } \quad \text { Median }}$

\section{With PEM}

Mean \pm SEM

Median

$\begin{array}{lll}0.96 & 1.59 \pm 0.33 & 1.15 \\ 5.33 & 5.41 \pm 1.09 & 3.95 \\ 2.77 & 5.11 \pm 1.21 & 4.13 \\ 2.66 & 6.19 \pm 2.52 & 1.48\end{array}$

HbSC subgroup

\begin{tabular}{ccccc}
0 & $1.44 \pm 0.47$ & 0.96 & $1.00 \pm 0.50$ & 0.43 \\
5 & $6.21 \pm 1.73$ & 4.51 & $3.78 \pm 2.66$ & 2.11 \\
10 & $5.09 \pm 1.33$ & 3.77 & $3.53 \pm 2.06$ & 2.04 \\
20 & $7.57 \pm 4.28$ & 4.37 & $8.47 \pm 5.85$ & 8.48 \\
\hline
\end{tabular}

Notes: Data are presented as means \pm standard error of the mean. Sample sizes are 13 without PEM vs 20 with PEM and 8 without PEM vs 4 with $\mathrm{PEM}$ for the $\mathrm{HbSS} / \mathrm{HbS} \beta^{\circ}$ and $\mathrm{HbSC}$ subgroups, respectively (interleukin-2 activity was not assayed in some of the samples). No significant differences were observed among children with and without PEM or between genotype subgroups. 


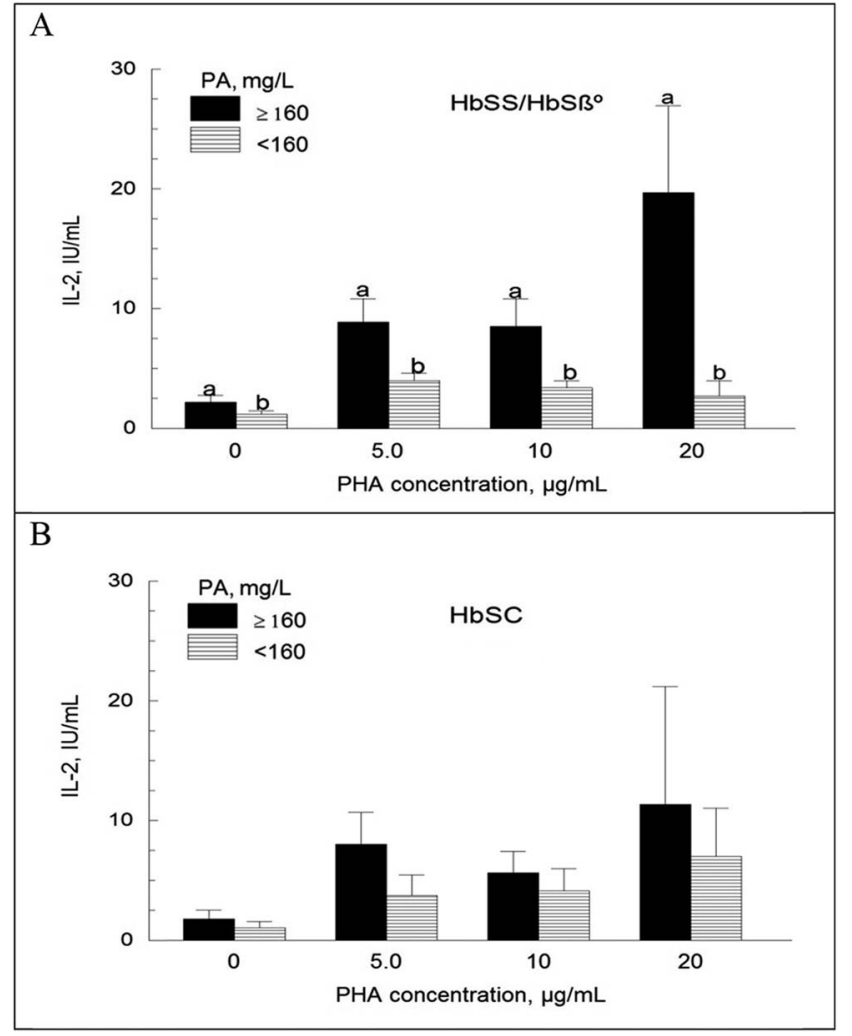

Figure 5. Interleukin-2 (IL-2) activity in blood mononuclear cell cultures as a function of prealbumin (PA) concentration. Blood mononuclear cells were incubated with and without phytohemagglutinin (PHA) for 48 hours. The supernatants were collected and tested for IL-2 biological activity on IL2-dependent (CTLL-2) cells. IL-2 was not measured in some of the cultures. Sample sizes are 9 vs 21 and 5 vs 6 in the $\mathrm{HbSS} / \mathrm{HbS}^{\circ}$ and $\mathrm{HbSC}$ subgroups, respectively. Values are means \pm standard error of the mean. For each PHA concentration, mean IL-2 biological activity (depicted as bars) with unlike superscript letters are significantly different $(a>b$; $P<0.05)$.

problems was worse than that of children without one or both of these problems.

4. Mean lymphocyte proliferative responses to PHA concentrations were reduced in children with RBP $\leq 20 \mathrm{mg} / \mathrm{L}$ and concentrations of $\mathrm{Alb}, \mathrm{PA}$, and $\mathrm{Tf}$ within normal range vs those with RBP $>20 \mathrm{mg} / \mathrm{L}$ and the other transport proteins within or below normal range. Our data therefore suggest that, in children with $\mathrm{HbSS} / \mathrm{HbS} \beta^{\circ}$ disease, mild to moderate malnutrition assessed by RBP alters (reduces) lymphocyte proliferation more so than malnutrition assessed by PA and Tf. Both these plasma proteins are also sensitive although not specific indicators of undernutrition. We do not believe that vitamin A status is the main factor in the association between low lymphocyte proliferative responses to PHA concentration and low RBP level because of the expected low prevalence of vitamin A deficiency in our patients as we previously reported. ${ }^{19}$
5. In parallel to the poorer nutritional status of children with $\mathrm{HbSS} / \mathrm{HbS}^{\circ}$ genotypes, their in vitro lymphocyte functions also were poorer than those of children with $\mathrm{HbSC}$.

6. This study showed a positive and significant correlation between IL-2 activity and PA but not with Alb, Tf, RBP, and $\mathrm{Hb}$ (Table 4). The lack of correlation between in vitro lymphocyte functions with some of the indicators of nutritional status could be related to the fact that we used normal $A B$ serum which is rich in various nutrients that could lead to in vitro repletion. Another possible explanation is the mild to moderate form of PEM in the study population. In fact, $<20 \%$ of children had 3 to 4 transport proteins below the normal range, and very few had growth deficits. The slight trend of higher lymphocyte proliferative responses to PHA concentration in children with the HbSC genotype with inflammation vs those without inflammation may suggest in vivo cell activation due to underlying unidentified disorders.

We did not investigate the mechanisms of impaired lymphocyte proliferation in children with the $\mathrm{HbSS} / \mathrm{HbS} \beta^{\circ}$ genotypes in the current study. However, we can speculate several possibilities: (i) differences in the number of immunocompetent $\left(\mathrm{CD}^{+}\right.$and $\left.\mathrm{CD}^{+}\right) \mathrm{T}$ lymphocytes between children with and without undernutrition, (ii) impaired gene expression of factors that regulate lymphocyte proliferative responses to mitogens, and (iii) altered ratios of effector to regulatory $\mathrm{T}$ cells and/or previous blood transfusion. ${ }^{33,34}$

The strengths of our study are the measurement of 4 transport proteins and 3 acute phase proteins for assessment of malnutrition and inflammation, respectively, and the overall sample size. The limitations of our study are the lack of data on mechanisms of impaired lymphocyte functions, plasma retinol concentrations (because vitamin A status regulates RBP biosynthesis), and age-matched African American children without SCD. Another limitation is the small sample size of children with Alb and Tf below the normal range.

\section{CONCLUSION}

Our study suggests that regardless of blood concentrations of Alb, Tf, and PA, children with $\mathrm{HbSS} / \mathrm{HbS} \beta^{\circ}$ genotypes who had RBP $\leq 20 \mathrm{mg} / \mathrm{L}$ had poorer lymphocyte proliferative responses to $\mathrm{PHA}$ concentrations than children with levels $>20 \mathrm{mg} / \mathrm{L}$. Inflammation was a confounding factor in altered lymphocyte proliferation in children with $\mathrm{HbSS} / \mathrm{HbS} \beta^{\circ}$ genotypes. Undernutrition did not reduce lymphocyte proliferation in children with the HbSC genotype. Lymphocyte proliferation was lower in the subgroup of children with the $\mathrm{HbSS} / \mathrm{HbS} \beta^{\circ}$ genotypes and undernutrition than in the children with the HbSC genotype. PA concentration below normal range was associated with reduced mean biological activity of IL-2. The association between mild malnutrition and reduced in vitro lymphocyte function requires further investigation in children with $\mathrm{HbSS}$ and/or $\mathrm{HbS} \beta^{\circ}$ disease, especially in countries where drugs such as hydroxyurea are less frequently used for the treatment of SCD. Dietary supplements may benefit children with the $\mathrm{HbSS} / \mathrm{HbS} \beta^{\circ}$ genotypes more than those with the $\mathrm{HbSC}$ genotype. 
Table 3. Effect of Inflammation on Interleukin-2 Activity in Phytohemagglutinin (PHA)-Treated Peripheral Blood Mononuclear Cells by Hemoglobin Genotype

Interleukin-2 Activity, IU/mL

\begin{tabular}{|c|c|c|c|c|}
\hline \multirow[b]{2}{*}{ PHA Concentration } & \multicolumn{2}{|c|}{$\mathrm{HbSS} / \mathrm{HbS} \beta^{\circ}$ Genotypes Subgroup } & \multicolumn{2}{|c|}{ HbSC Genotypes Subgroup } \\
\hline & $\begin{array}{c}\text { Without } \\
\text { Inflammation } \\
(n=19)\end{array}$ & $\begin{array}{c}\text { With } \\
\text { Inflammation } \\
(n=13)\end{array}$ & $\begin{array}{c}\text { Without } \\
\text { Inflammation } \\
(n=8)\end{array}$ & 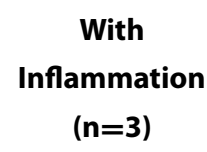 \\
\hline 0 & $1.37 \pm 0.33$ & $1.64 \pm 0.45$ & $1.39 \pm 0.50$ & $1.29 \pm 0.58$ \\
\hline 5 & $5.99 \pm 1.18$ & $4.73 \pm 1.13$ & $6.37 \pm 1.99$ & $3.78 \pm 2.66$ \\
\hline 10 & $5.23 \pm 1.34$ & $4.34 \pm 0.90$ & $4.76 \pm 1.38$ & $4.12 \pm 2.79$ \\
\hline 20 & $8.82 \pm 4.04$ & $3.74 \pm 2.10$ & $6.82 \pm 4.46$ & $\mathrm{~N} / \mathrm{A}$ \\
\hline
\end{tabular}

Notes: Data are presented as means \pm standard error of the mean. No significant difference was observed within and between groups of children with and without inflammation.

$\mathrm{N} / \mathrm{A}$, not available (interleukin-2 data were not available for some of the children).

Table 4. Correlation Coefficients (r) for Lymphocyte Proliferation (Stimulation Indexes) and Interleukin-2 Activity in Phytohemagglutinin (PHA)-Treated Peripheral Blood Mononuclear Cells and Markers of Nutritional and Hematologic Status in Children With Sickle Cell Disease

\begin{tabular}{|c|c|c|c|c|c|c|c|c|c|}
\hline \multirow[b]{2}{*}{ Marker } & \multicolumn{5}{|c|}{$\begin{array}{c}\text { Stimulation Indexes by PHA } \\
\text { Concentration }(\mu \mathrm{g} / \mathrm{mL}), \mathrm{r}\end{array}$} & \multicolumn{4}{|c|}{$\begin{array}{l}\text { Interleukin-2 (IL-2) Activity by } \\
\text { PHA Concentration ( } \mu \mathrm{g} / \mathrm{mL}), \mathrm{r}\end{array}$} \\
\hline & 2.5 & 5 & 10 & 15 & 20 & 0 & 5 & 10 & 20 \\
\hline Weight percentile & -0.123 & -0.116 & -0.046 & -0.116 & 0.030 & 0.0187 & 0.215 & 0.254 & 0.174 \\
\hline Albumin & -0.060 & -0.127 & -0.150 & -0.137 & -0.174 & $-0.348^{*}$ & -0.169 & $-0.319^{*}$ & $-0.588^{*}$ \\
\hline Prealbumin & 0.077 & 0.035 & 0.038 & -0.027 & -0.037 & $0.383^{*}$ & $0.516^{*}$ & $0.456^{*}$ & $0.542^{*}$ \\
\hline Transferrin & -0.022 & -0.118 & -0.135 & -0.132 & -0.142 & -0.146 & -0.233 & 0.086 & -0.145 \\
\hline Retinol binding protein & $0.294^{*}$ & $0.372^{*}$ & $0.357^{*}$ & $0.454^{*}$ & $0.440^{*}$ & -0.184 & -0.049 & -0.075 & 0.264 \\
\hline Hemoglobin & $0.294^{*}$ & $0.222^{*}$ & $0.246^{*}$ & 0.221 & $0.293^{*}$ & 0.022 & -0.059 & 0.046 & 0.210 \\
\hline White blood cell count & -0.160 & -0.106 & -0.141 & -0.087 & -0.124 & -0.200 & $-0.268^{*}$ & $-0.260^{*}$ & -0.095 \\
\hline
\end{tabular}

Notes: Children with the $\mathrm{HbSS}, \mathrm{HbS}^{\circ}$, and $\mathrm{HbSC}$ genotypes were included in the calculations of correlation coefficients. R values (coefficients) with asterisks are different from zero $(P<0.05)$. Some $P$ values $[\mathrm{r}]$ between weight and IL-2 and retinol binding protein and IL-2 that appear as if they should be significant are not significant because of sample size.

\section{ACKNOWLEDGMENTS}

We thank all parents who allowed their children to participate in the study, the nurses who coordinated blood drawing, and Mr Gerald Lane for assisting with cell cultures and the measurement of plasma proteins. Special thanks to Ms Leone Coe for her feedback and editing the manuscript. The authors have no financial or proprietary interest in the subject matter of this article.

\section{REFERENCES}

1. Cohen S, Danzaki K, Maclver NJ. Nutritional effects on T-cell immunometabolism. Eur JImmunol. 2017 Feb;47(2):225-235. doi: 10.1002/eji.201646423.

2. Ibrahim MK, Zambruni M, Melby CL, Melby PC. Impact of childhood malnutrition on host defense and infection. Clin Microbiol Rev. 2017 Oct;30(4):919-971. doi: 10.1128/CMR.00119-16.
3. Cunningham-Rundles $\mathrm{S}$. Evaluation of the effects of nutrients on immune function. In: Calder PC, Field CJ, Gill H, eds. Nutrition and Immune Function. Wallingford, UK: CABI Publishing, The Nutrition Society; 2002:21-39.

4. Rytter MJ, Kolte L, Briend A, Friis H, Christensen VB. The immune system in children with malnutrition-a systematic review. PLoS One. 2014 August 25;9(8):e105017. doi: 10.1371/journal.pone.0105017.

5. Zemel BS, Kawchak DA, Ohene-Frempong K, Schall JI, Stallings VA. Effects of delayed pubertal development, nutritional status, and disease severity on longitudinal patterns of growth failure in children with sickle cell disease. Pediatr Res. 2007 May;61(5 Pt 1):607-613. doi: 10.1203/pdr.0b013e318045bdca.

6. Bennett EL. Understanding growth failure in children with homozygous sickle-cell disease. J Pediatr Oncol Nurs. 2011 Mar-Apr;28(2):67-74. doi: 10.1177/1043454210382421.

7. Al-Saqladi AW, Cipolotti R, Fijnvandraat K, Brabin BJ. Growth and nutritional status of children with homozygous sickle cell 
disease. Ann Trop Paediatr. 2008 Sep;28(3):165-189. doi: $10.1179 / 146532808 \times 335624$.

8. Singhal A, Thomas P, Cook R, Wierenga K, Serjeant G. Delayed adolescent growth in homozygous sickle cell disease. Arch Dis Child. 1994 Nov;71(5):404-408. doi: 10.1136/adc.71.5.404.

9. Balandya E, Reynolds T, Obaro S, Makani J. Alteration of lymphocyte phenotype and function in sickle cell anemia: implications for vaccine responses. Am J Hematol. 2016 Sep;91(9):938-946. doi: 10.1002/ajh.24438.

10. Hyacinth $\mathrm{HI}$, Gee BE, Hibbert JM. The role of nutrition in sickle cell disease. Nutr Metab Insights. 2010 Jan 1;3:57-67. doi: 10.4137/NMI.S5048.

11. Khan SA, Damanhouri G, Ali A, et al. Precipitating factors and targeted therapies in combating the perils of sickle cell disease-a special nutritional consideration. Nutr Metab (Lond). 2016 Aug 8;13:50. doi: 10.1186/s12986-016-0109-7.

12. Hibbert JM, Hsu LL, Bhathena SJ, et al. Proinflammatory cytokines and the hypermetabolism of children with sickle cell disease. Exp Biol Med (Maywood). 2005 Jan;230(1):68-74. doi: $10.1177 / 153537020523000109$.

13. Martyres DJ, Vijenthira A, Barrowman N, Harris-Janz S, Chretien $C$, Klaassen RJ. Nutrient insufficiencies/deficiencies in children with sickle cell disease and its association with increased disease severity. Pediatr Blood Cancer. 2016 Jun;63(6):1060-1064. doi: 10.1002/pbc.25940.

14. Zemel BS, Kawchak DA, Fung EB, Ohene-Frepong K, Stallings VA. Effect of zinc supplementation on growth and body composition in children with sickle cell disease. Am J Clin Nutr. 2002 Feb;75(2):300-307. doi: 10.1093/ajcn/75.2.300.

15. Hasanato RM. Zinc and antioxidant vitamin deficiency in patients with sickle cell anemia. Ann Saudi Med. 2006 Jan-Feb;26(1):17-21. doi: 10.5144/0256-4947.2006.17.

16. Prasad AS, Beck FW, Kaplan J, et al. Effect of zinc supplementation on incidence of infections and hospital admissions in sickle cell disease (SCD). Am J Hematol. 1999 Jul;61(3):194-202. doi: 10.1002/(sici)10968652(199907)61:3 < 194::aid-ajh6>3.0.co;2-c.

17. Heyman MB, Vichinsky E, Katz R, et al. Growth retardation in sickle cell disease treated by nutritional support. Lancet. 1985 Apr 20;1(8434):903-906. doi: 10.1016/s0140-6736(85)91677-0.

18. Kuvibidila S, Gardner R, Ode D, Yu L, Lane G, Warrier RP. Tumor necrosis factor alpha in children with sickle cell disease in stable condition. J Natl Med Assoc. 1997 Sep;89(9):609-615.

19. Kuvibidila S, Gardner R, Velez M, Warrier R. Clinical observations, plasma retinol concentrations, and in vitro lymphocyte functions in children with sickle cell disease. Ochsner J. 2018 Winter;18(4):308-317. doi: 10.31486/TOJ.17.0044.

20. Warrier RP, Kuvibidila S, Gordon L, Humbert J. Transport proteins and acute phase reactant proteins in children with sickle cell anemia. J Natl Med Assoc. 1994 Jan;86(1):33-39. Erratum in: J Natl Med Assoc. 1994 Jul;86(7):515.

21. Kuvibidila SR, Sandoval M, Lao J, et al. Plasma zinc levels inversely correlate with vascular cell adhesion molecule-1 concentration in children with sickle cell disease. J Nat/ Med Assoc. 2006 Aug;98(8):1263-1272.

22. Quinn CT. Minireview: clinical severity in sickle cell disease: the challenges of definition and prognostication. Exp Biol Med (Maywood). 2016 Apr;241 (7):679-688. doi: $10.1177 / 1535370216640385$.

23. Gibson SR. Assessment of protein status. In: Gibson SR, ed. Principles of Nutritional Assessment. 2nd ed. New York, NY: Oxford University Press; 2005:403-442.

24. Beck KF, Rosenthal TC. Prealbumin: a marker for nutritional evaluation. Am Fam Physician. 2002 Apr 15;65(8):1575-1578. Erratum in: Am Fam Physician. 2002 Dec 15;66(12):2208.

25. C-reactive protein concentrations as a marker of inflammation or infection for interpreting biomarkers of micronutrient status. World Health Organization. www.who.int/nutrition/ publications/micronutrients/indicators_c-reactive_protein/en/. Published 2014.

26. Thurnham DI, McCabe GP. Influence of infection and inflammation on biomarkers of nutritional status with an emphasis on vitamin A and iron. World Health Organization Report: priorities in the assessment of vitamin A and iron status in populations. www.who.int/nutrition/publications/ micronutrients/background_paper4_report_assessment vitAandlron_status.pdf. Published 2012.

27. Zito DR, Johnson KL, Skipper ME, Normansell DE. Isolation of mononuclear cells from whole blood: comparison of two media. Lab Medicine. 1986 Feb 1;17(2):94-95.

28. Hank JA, Surfus J, Gan J, et al. Distinct clinical and laboratory activity of two recombinant interleukin-2 preparations. Clin Cancer Res. 1999 Feb;5(2):281-289.

29. Munro HB. Differences among group means: one way analysis of variance. In: Munro HB, Page IB, eds. Statistical Methods for Health Care Research. 2nd ed. Philadelphia, PA: JB Lippincott Company; 1993:99-128.

30. Taylor S, Shacks S, Villicana S, Olivares J, Dinkins G. Lymphocyte blastogenic responses in sickle cell disease. Immunol Invest. 1991 Dec;20(7):645-655. doi: 10.3109/08820139109026244.

31. Taylor SC, Shacks SJ, Mitchell RA. In vitro lymphocyte blastogenic responses and cytokine production in sickle cell disease patients with acute pneumonia. Pediatr Infect Dis J. 1996 Apr;15(4):340-344. doi: 10.1097/00006454-199604000-00011.

32. Taylor S, Shacks S, Qu Z, Colaco V. In vitro suppression of the normal mitogenic T lymphocyte response by steady state sickle cell disease sera. Immunol Invest. 1997 Aug-Dec; 26(5-7):561-568. doi: 10.3109/08820139709088540.

33. Macian F. NFAT proteins: key regulators of T-cell development and function. Nat Rev Immunol. 2005 Jun;5(6):472-484. doi: 10.1038/nri1632.

34. Serjeant GR. The natural history of sickle cell disease. Cold Spring Harb Perspect Med. 2013 Oct 1;3(10):a011783. doi: 10.1101/cshperspect.a011783.

This article meets the Accreditation Council for Graduate Medical Education and the American Board of Medical Specialties Maintenance of Certification competencies for Patient Care, Medical Knowledge, and Practice-Based Learning and Improvement.

(C)2020 by the author(s); licensee Ochsner Journal, Ochsner Clinic Foundation, New Orleans, LA. This article is an open (c) access article distributed under the terms and conditions of the Creative Commons Attribution (CC BY) license (creativecommons.org/licenses/by/4.0/legalcode) that permits unrestricted use, distribution, and reproduction in any medium, provided the original author(s) and source are credited. 